\title{
HUBUNGAN ANTARA MINAT BELAJAR EVALUASI PEMBELAJARAN PENJAS DENGAN HASIL BELAJAR EVALUASI PEMBELAJARAN PENJAS KELAS 17B FKIP UNIVERSITAS HALU OLEO
}

\author{
oleh: \\ SUHARTIWI \\ Dosen Program Studi Pendidikan Jasmani, Kesehatan dan Rekreasi Fakultas Keguruan \\ dan Ilmu Pendidikan Universitas Halu Oleo \\ Email: suhartiwi takraw05@yahoo.com
}

\begin{abstract}
ABSTRAK
penelitian ini bertujuan untuk mengetahui hubungan antara minat belajar evaluasi pembelajaran penjas dengan hasil belajar evaluasi pembelajaran penjas mahasiswa Penjaskesrek kelas 17B FKIP UHO. Jenis penelitian ini adalah expostfacto dengan rancangan regresional. Subjek penelitian ini adalah seluruh mahasiswi Penjaskesrek kelas 17B FKIP UHO yang sedang memprogram mata kuliah Evaluasi Pembelajaran Penjas sebanyak 55 mahasiswa. Teknik pengambilan data dengan menggunakan tes dan pengukuran minat belajar mahasiswa dan tes hasil belajar mahasiswa pada matakuliah Evaluasi Pembelajaran Penjas. Hasil analisis data menunjukan bahwa terdapat hubungan yang signifikan antara minat belajar evaluasi pembelajaran penjas dengan hasil belajar evaluasi pembelajaran penjas mahasiswa Penjaskesrek kelas 17B FKIP UHO.
\end{abstract}

\section{Kata Kunci: Minat Belajar, Hasil Belajar, Evaluasi Pembelajaran Penjas}

\section{PENDAHULUAN}

Pendidikan pada hakikatnya mencakup kegiatan mendidik, mengajar dan melatih. Kegiatan tersebut dilaksanakan sebagai suatu usaha untuk mentransformasikan nilai-nilai. Nilainilai yang akan ditransformasikan itu mencakup nilai-nilai religi, nilai kebudayaan, pengetahuan dan teknologi serta nilai keterampilan. Nilai-nilai yang akan ditransformasikan tersebut dalam rangka mempertahankan, mengembangkan, bahkan kalau perlu mengubah kebudayaan yang dimiliki masyarakat.
Mulayani mengungkapkan bahwa belajar dapat memungkinkan seserang mengalami perubahan dalam dirinya. Perubahan yang dialami tersebut dapat berupa penguasaan suatu kecakapan tertentu, perubahan sikap dan memiliki ilmu pengetahuan yang berbeda dari sebelum sesemahasiswa melakukan proses pembelajaran.

Perubahan-perubahan yang terjadi dalam diri mahasiswa merupakan buah dari usaha yang telah dilakukan selama proses pembelajaran. Buah dari proses pembelajaran inilah yang disebut hasil belajar. Perubahan yang terjadi sebagai aikibat dari hasil belajar akan membantu individu berinteraksi di lingkungan sekitarnya baik di 
masyarakat maupun di lembaga kependidikan. Hal senada diungkap oleh Purwanto bahwa hasil belajar merupakan perubahan yang mengakibatkan manusia berubah dalam tingkah laku dan secara khusus pengetahuannya.

Kondisi di lapangan menunjukkan bahwa hasil belajar mahasiswa utamanya pada mata kuliah evaluasi pembelajaran penjas cenderung masih rendah. Salah satu penyebabnya karena kurangnya minat untuk mempelajari mata kuliah evaluasi pembelajaran penjas. Artinya, mahasiswa tidak mengalami ketertarikan untuk mempelajari evaluasi pembelajaran penjas dan menganggap bahwa evaluasi pembelajaran penjas lebih sulit dari mata kuliah lainnya.

Purwanto mengungkapkan hasil belajar dapat dijelaskan dengan memahami dua kata yang membentuknya, yaitu hasil dan belajar. Pengertian hasil menunjuk pada suatu perolehan akibat dilakukannya suatu aktivitas atau proses yang mengakibatkan berubahnya input secara fungsional. Jadi hasil belajar merupakan perubahan yang mengakibatkan manusia berubah dalam tingkah laku dan secara khusus pengetahuannnya. Nana Sudjana menjelaskan bahwa hasil belajar adalah suatu proses yang ditandai dengan adanya perubahan pada diri sesemahasiswa. Perubahan sebagai hasil dari proses belajar ditunjukkan dalam berbagai bentuk seperti perubahan sikap, tingkah laku serta perubahan aspek lain yang ada pada individu yang belajar.

Lebih lanjut $\begin{array}{r}\text { Rohwati } \\ \text { belajar }\end{array}$
mengungkapkan hasil
merupakan hal yang penting yang akan
dijadikan tolok ukur keberhasilan

peserta didik dalam belajar dan sejauh mana sistem pembelajaran yang diberikan guru berhasil atau tidak. Suatu proses belajar mengajar dikatakan berhasil apabila kompetensi dasar yang diinginkan tercapai.

Berdasarkan penjelasan di atas dapat disimpulkan bahwa hasil belajar adalah kemampuan yang dimiliki peserta didik setelah melakukan aktivitas belajar yang ditandai oleh tercapainya suatu tujuan belajar berupa perubahan tingkah laku, bertambahnya pengetahuan dan memiliki suatu keterampilan.

Nana Sudjana mengungkapkan bahwa hasil belajar dibagi menjadi tiga, yakni:

1) Ranah kognitif

2) Ranah afektif

3) Ranah psikomotoris

Adapun faktor yang memperngaruhi hasil belajar ada dua macam, yakni faktor intern (berasal dari dalam diri mahasiswa) dan faktor ekstern (berasal dari luar diri mahasiswa). Faktor dari dalam diri peserta didik (intern) ada tiga macam yakni a) Faktor jasmani; b) Faktor Psikologis; c) Faktor kelelahan. Faktor yang berasal dari luar (ekstern) juga ada 3 macam yaitu a) Faktor keluarga; b) Faktor kampus; dan c) Faktor lingkungan Masyarakat.

Slameto dalam bukunya menuliskan bahwa minat adalah kecenderungan yang tetap untuk memperhatikan dan mengenang beberapa kegiatan. Kegiatan yang diminati Mahasiswa, diperhatikan terusmenerus yang disertai rasa senang dan diperoleh rasa kepuasan. Lebih lanjut dijelaskan minat adalah suatu rasa suka dan ketertarikan pada suatu hal atau 
aktivitas, tanpa ada yang menyuruh. Sesemahasiswa yang memiliki minat terhadap kegiatan tertentu cenderung memberikan perhatian yang besar terhadap kegiatan tersebut.

Senada dengan hal tersebut di atas, Muhibbin Syah mengungkapkan minat adalah kecenderungan atau kegairahan hati yang tinggi atau keinginan yang besar terhadap sesuatu. Apabila smahasiswa telah memiliki keinginan maka sedapat mungkin akan melakukan segala sesuatu untuk memperolehnya. Lebih lanjut Slameto mengungkapkan minat adalah suatu rasa lebih suka danrasa ketertarikan pada suatu hal atau aktivitas, tanpa ada yang menyuruh.

Berdasarkan beberapa pengertian diatas terdapat banyak kesamaan yang diungkapkan para ahli mengenai pengertian minat, maka penulis menyimpulkan minat belajar adalah kecenderungan hati sesemahasiswa untuk melakukan suatu kegiatan (belajar) tanpa disertai adanya paksaan dari luar individu. Minat membuat semahasiswa merasakan kegairahan dalam melakukan pekerjaan tertentu disebabkan oleh perasaan senang yang ada dalam dirinya.

Minat mahasiswa terhadap Mata Kuliah dapat dilihat dari kecenderungan untuk memberikan perhatian yang lebih besar terhadap mata kuliah tersebut. Bila sesemahasiswa mempunyai minat yang besar terhadap mata kuliah evaluasi pembelajaran penjas maka nilai hasil belajarnya cenderung berubah ke arah yang lebih baik. Hal tersebut juga berlaku sebaliknya, jika minat.

Minat belajar evaluasi pembelajaran penjas yang dimaksud adalah minat mahasiswa terhadap mata kuliah evaluasi pembelajaran penjas yang ditandai oleh perhatian mahasiswa pada mata kuliah evaluasi pembelajaran penjas, kesukaaan mahaiswa terhadap mata kuliah evaluasi pembelajaran penjas, keinginan mahasiswa untuk tahu lebih banyak mengenai evaluasi pembelajaran penjas, tugas-tugas yang diselesaikan oleh mahasiswa, motivasi mahasiswa mempelajari evaluasi pembelajran, kebutuhan mahasiswa terhadap mata kuliah evaluasi pembelajaran penjas dan ketekunan mahasiswa dalam mempelajari evaluasi pembelajaran penjas. Kurangnya minat belajar mahasiswa terhadap evaluasi pembelajaran penjas karena kurangnya pengertian tentang hakekat dan fungsi itu sendiri. Padahal evaluasi pembelajaran penjas merupakan salah satu ilmu yang harus dimiliki oleh mahasiswa ketika menjadi guru pendidikan jasmani

Berdasarkan uraian di atas, maka minat belajar evaluasi pembelajaran penjas adalah perasaan senang terhadap mata kuliah evaluasi pembelajaran penjas dimana mahasiswa menaruh perhatian yang besar terhadap evaluasi pembelajaran penjas dan menjadikan evaluasi pembelajaran penjas mata kuliah yang mudah.

Sumadi Suryabrata mengungkapkan minat mempunyai ketergantungan pada faktor internal seperti perhatian dan kebutuhan. Berikut uraian dari beberapa indikator minat tersebut.

\section{Perhatian}

Perhatian sangatlah penting dalam mengikuti kegiatan dengan baik dan hal ini akan berpengaruh pula terhadap minat peserta didik dalam belajar. Perhatian dalam belajar yaitu pemusatan 
atau konsentrasi dari seluruh aktivitas sesemahasiswa yang ditujukan kepada sesuatu atau sekumpulan objek belajar. peserta didik yang aktifitas belajarnya disertai dengan perhatian yang intensif akan lebih sukses, serta prestasinya akan lebih tinggi. Mahasiswa yang menaruh minat pada suatu aktivitas akan memberikan perhatian yang besar. Ia tidak segan mengorbankan waktu dan tenaga demi aktivitas tersebut. Oleh karena itu semahasiswa peserta didik yang mempunyai perhatian terhadap suatu pelajaran, ia pasti akan berusaha keras untuk memperoleh nilai yang bagus yaitu dengan belajar.

\section{Kebutuhan}

Kebutuhan (motif) yaitu keadaan dalam diri pribadi semahasiswa peserta didik yang mendorongnya untuk melakukan aktifitas-aktifitas tertentu guna mencapai suatu tujuan. Kebutuhan ini hanya dapat dirasakan sendiri oleh semahasiswa individu. Sesemahasiswa melakukan aktivitas belajar karena ada yang mendorongnya. Motivasi sebagai dasar penggeraknya yang mendorong sesemahasiswa untuk belajar. Dan minat merupakan potensi psikologi yang dapat dimanfaatkan untuk menggali motivasi bila sesemahasiswa sudah termotivasiuntuk belajar, maka dia akan melakukan aktivitas belajar dalam rentangan waktu tertentu.

Abdul Rahman Saleh berpendapat ada tiga faktor yang mempengaruhi timbulnya minat, yaitu:

\section{Dorongan dari dalam diri individu}

Dorongan yang terjadi dalam diri individu berupa dorongan untuk makan, belajar, berpikir dan sebagainya. Dorongan untuk makan akan membangkitkan minat untuk bekerja atau mencari penghasilan, minat terhadap produksi makanan dan lain lain. Dorongan ingin tahu atau rasa ingin tahu akan membangkitkan minat untuk membaca, belajar, menuntut ilmu, melakukan penelitian dan lain lain.

\section{Motif sosial}

Motif sosial dapat menjadi faktor yang membangkitkan minat untuk melakukan suatu aktivitas tertentu, misalnya minat terhadap pakaian timbul karena ingin mendapat persetujuan atau penerimaan dan perhatian mahasiswa lain. Minat untuk belajar atau menuntut ilmu pengetahuan timbul karena ingin mendapat penghargaan dari masyarakat, karena biasanya yang memiliki ilmu pengetahuan cukup luas (mahasiswa pandai) mendapat kedudukan yang tinggi dan terpandang dalam masyarakat.

\section{Faktor emosional}

Minat mempunyai hubungan yang erat dengan emosi. Bila sesemahasiswa mendapatkan kesuksesan pada aktivitas akan menimbulkan perasaan senang, dan hal tersebut akan memperkuat minat terhadap aktivitas tersebut, sebaliknya suatu kegagalan akan menghilangkan minat terhadap hal tersebut.

Proses belajar mengajar evaluasi pembelajaran penjas yang baik adalah dosen harus mampu menerapkan suasana yang dapat membuat murid antusias terhadap persoalan yang ada sehingga mampu mencoba memecahkan persoalannya. Dosen juga harus mampu mengantarkan mahasiswanya kepada pemahaman yang benar bahwa pentingnya mata kuliah evaluasi pembelajaran penjas sebelum memulai suatu pembelajaran. Agara mahasiswa 
dapat fokus mengikuti mata kuliah tersebut karena telah mengetahui tujuan dari materi yang akan diajarkan

Banyak faktor yang
mempengaruhi hasil belajar mahasiswa diantaranya faktor internal yang berasal dari dalam diri sesemahasiswa. Salah satu faktor internal yang mempengeruhi hasil belajar adalah minat belajar yang dimiliki oleh masing-masing mahasiswa. Minat belajar yang dimaksud disini adalah ketertarikan mahasiswa dalam sebuah mata kuliah. Ada mahasiswa yang memiliki minat belajar tinggi yang berarti mahasiswa tersebut memiliki peluang besar untuk memahami suatu materi mata kuliah , ada juga siswa yang memiliki minat belajar sedan sedang yang berarti mahasiswa tersebut memiliki peluang yang cukup untuk memahami mata kuliah dan terakhir siswa yang memiliki minat belajar rendah yang berarti peluang dalam menerima pelajaran lambat.

\section{METODE PENELITIAN}

Penelitian ini hendak mengkaji tentang hubungan minat belajar dengan hasil belajar Mahasiswa jurusan penjaskesrek kelas 17B FKIP UHO Pendekatan yang digunakan dalam penelitian ini adalah pendekatan kuantitatif. Pendekatan kuantitatif yaitu penelitian yang banyak dituntut menggunakan angka, mulai dari pengumpulan data, penafsiran terhadap data tersebut, serta penampilan dari hasilnya.

Jenis penelitian ini adalah ex-post facto menggunakan metode korelasi.Suharsimi juga mengemukakan bahwa penelitian korelasional bertujuan untuk menemukan ada tidaknya hubungan dan apabila ada, berapa eratnya hubungan serta berarti atau tidak hubungan itu. Penelitian korelasi juga bertujuan untuk membandingkan hasil pengukuran antara dua variabel yang berbeda sehingga dapat ditentukan tingkat hubungan antara variabelvariabel. Dari definisi tersebut, maka jenis penelitian dalam penelitian ini adalah korelasional.

Desain penelitian ini adalah paradigma sederhana dengan satu variabel indipenden dan satu variabel dependen. Adapun desain penelitiannya adalah:

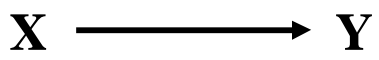

Dimana:

$X$ : Minat Belajar evaluasi pembelajaran penjas

Y : Hasil Belajar

\section{Lokasi dan Waktu Penelitian}

Penelitian ini dilaksanakan di Fakultas Keguruan dan Ilmu Pendidikan Universitas Halu Oleo dengan judul penelitian Hubungan antara Minat Belajar evaluasi pembelajaran penjas dengan Hasil Belajar mahasiswa di jurusan Penjaskesrek Kelas 17B FKIP UHO

\section{Populasi dan Sampel}

Populasi dalam penelitian ini adalah seluruh Mahasiswa Penjaskesrek kelas17B FKIP UHO yang memprogram mata kuliah evaluasi pembelajaran penjas. Sampel adalah bagian dari suatu populasi.Setelah diobservasi ternyata jumlah mahasiswa kelas 17B secara keseluruhan adalah 55 mahasiswa. Pengambilan sampel dilakukan dengan menggunakan sampling jenuh. Sugiyono mengatakan 
bahwa sampling jenuh adalah teknik penentuan sampel bila semua anggota populasi digunakan sebagai sampel.

Suharsimi Arikunto menyatakan prosedur pembuatan instrumen meliputi beberapa hal, yaitu: a) mendefinisikan variabel secara operasional, b) menentukan indikator, c) membuat kisikisi, d) penyusunan item, e) penetapan skor, dan f) uji coba instrumen. Penelitian yang digunakan dalam instrumen yang dikembangkan adalah skala psikologi minat belajar dengan empat pilihan jawaban. Pernyataan tersebut diukur dengan skala likert.

Skala minat belajar disusun berdasarkan teori yang diungkapkan oleh Elizabeth B. Hurlock bahwa minat belajar adalah salah satu indikator yang dapat membuat peserta didik bersemangat dalam belajar. Minat belajar terdiri atas dua aspek, yaitu aspek kognitif, afektif dan psikomotor. Kisi-kisi skala minat belajar dapat dilihat pada tabel di bawah:

Tabel 1. Kisi-Kisi Minat Belajar Evaluasi Pembelajaran Penjas

\begin{tabular}{|c|c|c|c|}
\hline \multirow{2}{*}{ Aspek } & \multirow{2}{*}{ Indikator } & \multicolumn{2}{|c|}{ Nomor Item } \\
\hline & & Favorabel & unfavorable \\
\hline \multirow{2}{*}{ 1. Afektif } & a. Perasaan senang & $1,2,3$ & $4,5,6$ \\
\hline & b. Rasa tertarik & $7,8,9$ & $10,11,12$ \\
\hline 2. Kognitif & a. Perhatian & $13,14,15$ & $16,17,18$ \\
\hline 3. Psikomotorik & a. Partisipasi & $19,20,21$ & $22,23,24$ \\
\hline
\end{tabular}

Dokumentasi adalah mencari data mengenai hal-hal atau variabel yang berupa catatan, transkrip, buku, surat kabar, parasit, notulen rapat, legger, agenda, dan sebagainya. Metode dokumentasi atau teknik dokumentasi adalah suatu cara yang digunakan untuk mengumpulkan data yang ditunjukkan untuk memperoleh penjelasan melalui sumber-sumber dokumen. Jenis dokumentasi yang digunakan dalam penelitian ini adalah hasil belajar evaluasi pembelajaran penjas berupa nilai mii semester genap tahun akademik 2018/2019.

Kegiatan yang dilakukan dalam analisis data adalah mengelompokkan data berdasarkan variabel, mentabulasi data berdasarkan variabel dari seluruh responden, menyajikan data tiap variabel yang diteliti, menghitung agar rumusan masalah terjawab, dan menghitung untuk uji hipotesis. Teknik analisis data yang digunakan dalam penelitian ini adalah statistik deskriptif dan statistik inferensial dengan menggunakan bantuan program SPSS 16.

\section{HASIL DAN PEMBAHASAN}

\section{Hasil Penelitian}

\section{Hasil Analisis Deskriptirf Minat Belajar dan Hasil Belajar Mahasiswa Penajakesrek kelas 17B FKIP UHO}

Tabel 1. Nilai Statistik Deskriptif Minat belajar dan Hasil Belajar Mahasiswa Penjaskesrek Kelas 17B FKIP UHO 


\begin{tabular}{lcc}
\hline & $\begin{array}{l}\text { Minat } \\
\text { Belajar }\end{array}$ & $\begin{array}{l}\text { Hasil } \\
\text { Belajar }\end{array}$ \\
\hline Jumlah sampel & 55 & 55 \\
Skor minimal & 50 & 76 \\
Skor maksimal & 70 & 96 \\
Rentang & 20 & 20 \\
Rata - rata & 58,55 & 85,73 \\
Simpang baku & 3,790 & 5,265 \\
Varians & 14,364 & 27,721 \\
\hline
\end{tabular}

Berdasarkan tabel 1. diatas jumlah sampel masing-masing variabel minat belajar dan hasil belajar adalah 55 mahasiswa. Pada variabel minat belajar skor minimalnya adalah 5 dan skor maksimalnya adalah 7 , sedangkan pada variabel hasil belajar skor minimalnya adalah 76 dan skor maksimalnya adalah 96. Pada variabel minat belajar nilai rentangnya adalah 20 dan variabel hasil belajar nilai rentangnya adalah 20 . Pada variabel minat belajar nilai rata-ratanya adalah 58,55 dan pada variabel hasil belajar nilai rata-ratanya adalah 85,73 . Pada variabel minat belajar nilai simpang bakunya adalah 3,790 dan nilai variansnya adalah 14,364, sedangkan pada variabel hasil belajar nilai simpang bakunya adalah 5,265 dan nilai variansnya adalah 27,721 .

\section{Hasil Analisis infernesial Minat Belajar dan Hasil Belajar Mahasiswa Penajakesrek kelas 17B FKIP UHO}

\section{a) Normalitas data}

1. Uji normalitas minat belajar mahasiswa Penjaskesrek kelas 17B FKIP UHO

Berdasarkan hasil analisis minat belajar mahasiswa Penjaskesrek kelas 17B FKIP UHO menunjukkan bahwa Pvalue $>0,05$, yaitu $0,711>0,05$ yang berarti bahwa sampel berasal dari populasi yang berdistribusi normal.
2. Uji normalitas hasil belajar mahasiswa Penjaskesrek kelas 17B FKIP UHO

Berdasarkan hasil analisis hasil belajar mahasiswa Penjaskesrek kelas 17B FKIP UHO menunjukkan bahwa Pvalue $>0,05$, yaitu $0,618>0,05$ yang berarti bahwa sampel berasal dari populasi yang berdistribusi normal.

Tabel 2. Rangkuman Uji Normalitas Minat dan Hasil Belajar Mahasiswa Penjaskesrek Kelas 17B FKIP UHO

\begin{tabular}{lccc}
\hline & N & P-value & Kesimpulan \\
\hline $\begin{array}{l}\text { Minat } \\
\text { Belajar }\end{array}$ & 55 & 0,711 & Normal \\
$\begin{array}{l}\text { Hasil } \\
\text { Belajar }\end{array}$ & 55 & 0,618 & Normal \\
\hline
\end{tabular}

\section{b) Homogenitas data}

Hasil analisis uji homogenitas varians antara minat belajar dengan hasil belajar mahasiswa Penjaskesrek kelas 17B FKIP UHO, diperoleh nilai $\mathrm{P}$-value $=$ 0,641. Karena nilai P-value $>0,05$ maka dapat diambil kesimpulan bahwa tidak ada perbedaan varians antar kelompok data yang dibandingkan dengan kata lain varians data adalah sama (homogen).

Tabel 3. Rangkuman Uji Homogenitas Minat Belajar dengan Hasil Belajar Mahasiswa Penjaskesrek Kelas 17B FKIP UHO

\begin{tabular}{llc}
\hline \multicolumn{1}{c}{ Varians } & $\begin{array}{l}\text { P- } \\
\text { Value }\end{array}$ & Kesimpulan \\
\hline $\begin{array}{l}\text { Minat Belajar } \\
\text { dengan }\end{array}$ & 0,641 & Homogen \\
Hasil Belajar & & \\
\hline
\end{tabular}




\section{c) Pengujian hipotesis}

Tabel 4. Rangkuman Hasil Analisis Regresional Minat Belajar dengan Hasil Belajar Mahasiswa Penjaskesrek Kelas 17B FKIP UHO

\begin{tabular}{llllll}
\hline Model & $\begin{array}{l}\text { Jumla } \\
\text { h } \\
\text { Kuadr } \\
\text { at }\end{array}$ & Df & $\begin{array}{l}\text { Rata- } \\
\text { rata } \\
\text { Kuadr } \\
\text { at }\end{array}$ & F & $\boldsymbol{P}$ \\
\hline 1 & & 2 & 37,286 & 20,530 & 0,000 \\
\hline Regresi & 74,571 & 2 & & &
\end{tabular}

Dari tabel 4. di atas diperoleh F sebesar 20,530 dengan signifikansi 0,000 . Karena nilai signifikansi kurang dari 0,05 maka dapat diambil keputusan tolak $\mathrm{H}_{0}$. Artinya terdapat hubungan yang signifikan anatara minat belajar dengan hasil belajar mahasiswa Penajaskesrek kelas 17B FKIP UHO.

\section{Pembahasan}

Pengertian diatas terdapat banyak kesamaan yang diungkapkan para ahli mengenai pengertian minat, maka penulis menyimpulkan minat belajar adalah kecenderungan hati sesemahasiswa untuk melakukan suatu kegiatan (belajar) tanpa disertai adanya paksaan dari luar individu. Minat membuat mahasiswa merasakan kegairahan dalam melakukan pekerjaan tertentu disebabkan oleh perasaan senang yang ada dalam dirinya.

Berdasarkan uraian di atas, maka minat belajar evaluasi pembelajaran penjas adalah perasaan senang terhadap mata kuliah evaluasi pembelajaran penjas dimana mahasiswa menaruh perhatian yang besar terhadap evaluasi pembelajaran penjas dan menjadikan evaluasi pembelajaran penjas mata kuliah yang mudah
Penjelasan di atas dapat disimpulkan bahwa hasil belajar adalah kemampuan yang dimiliki peserta didik setelah melakukan aktivitas belajar yang ditandai oleh tercapainya suatu tujuan belajar berupa perubahan tingkah laku, bertambahnya pengetahuan dan memiliki suatu keterampilan.

\section{Hubungan minat belajar dengan hasil belajar mahasiswa Penjaskesrek kelas 17B FKIP UHO}

Minat belajar adalah kecenderungan hati sesemahasiswa untuk melakukan suatu kegiatan (belajar) tanpa disertai adanya paksaan dari luar individu. Minat membuat mahasiswa merasakan kegairahan dalam melakukan pekerjaan tertentu disebabkan oleh perasaan senang yang ada dalam dirinya. Sedangkan bahwa hasil belajar adalah kemampuan yang dimiliki peserta didik setelah melakukan aktivitas belajar yang ditandai oleh tercapainya suatu tujuan belajar berupa perubahan tingkah laku, bertambahnya pengetahuan dan memiliki suatu keterampilan.

Dengan adanya minat yang kuat dari setiap mahasiswa yang mengikuti setiap matakuliah dapat memberikan hasil yang positif terhadap hasil belajar setiap mahasiswa tersebut.

\section{KESIMPULAN DAN SARAN}

\section{Kesimpulan}

Berdasarkan hasil pengumpulan data, pengolahan data dan hasil penelitian yang diperoleh yang telah dikemukakan sebelumnya, maka dapat disimpulkan bahwa ada hubungan yang signifikan antara minat belajar dengan hasil belajar mahasiswa Penjaskesrek kelas 17B 
FKIP UHO pada matakuliah Evaluasi Pembelajaran Penjas.

\section{DAFTAR PUSTAKA}

Arikunto, Suharsimi. Dasar-Dasar Evaluasi. Jakarta: Bumi Aksara, 2006.

Arikunto, Suharsimi.Prosedur Penelitian Suatu Pendekatan praktik. Jakarta: Rineka Cipta, 2006.

Arifin, Zainal.Evaluasi Pembelajaran. Cet. Kelima; Bandung: PT Rosdakarya Offset.

Djamarah, Syaiful Bahri.Strategi Belajar Mengajar. Jakarta: Rineka Cipta, 2002.

Mulyani, Dessy.Hubungan Kesiapan Belajar Siswa dengan Prestasi Belajar. Jurnal Ilmiah Konseling vol. 2 no. $1,2013$.

Purwanto. Evaluasi Hasil Belajar. Cet.III; Yogyakarta: Pustaka Pelajar, 2011

Riduwan. Belajar Mudah Penelitian untuk Guru-Karyawan dan Peneliti Pemula. Banduna: Alfabeta, 2012.

Riduwan dan Susanto.Pengantar Statistika: Untuk Penelitian Pendidikan, sosial, ekonomi komunikasi dan bisnis. Bandung: Alfabeta, 2009.

Sari, Ressa Arsita.Hubungan Minat Belajar Siswa dengan Hasil Belajar IPS di Gugus 1 Kabupaten Kepahlang. skripsi; Fakultas Keguruan dan Ilmu Pendidikan:Universitas Bengkulu, 2014.

Shaleh, Abdul Rahman. Psikologi Suatu Pengantar Dalam Perspektif Islam. Jakarta: Predana Media, 2004.
Slameto. Belajar dan Faktor-Faktor yang Mempengaruhi. Bandung: Remaja Rosdakarya, 2010.

Sudjana, Nana. Evaluasi Hasil Belajar. Cet.XIII; Bandung: PT Remaja Rosdakarya, 2009.

Sudjana, Nana.Statistika Pendidikan. Cet. I; Bandung: Remaja Rosdakarya, 1996.

Sugiyono.Statistika Untuk Penelitian. Ed. XX; Bandung: Alfabeta, 2012.

Syah, Muhibbin.Psikologi Belajar. Cet.1; Jakarta: Logos, 1999.

Wahidmurni.Cara Mudah menulis Proposal dan Laporan Penelitian Lapangan.Malang: UM Press, 2008. 